\title{
The principles of Ubuntu: Using the legal clinical model to train agents of social change
}

\author{
Professor Nekima Levy-pounds Esq \\ and \\ Artika Tyner Esq ${ }^{1}$
}

For the past few decades, the legal clinical model has been used as a tool to teach law students the art of practising law. ${ }^{2}$ Typically, this model focuses on providing law students with an opportunity to work with clients and to handle legal cases in a safe environment, and often in slow motion. ${ }^{3}$ Although the legal clinical model has a number of advantages in assisting students to safely transition from law students to lawyers, it falls short in stressing the importance of using the law as a tool to achieve social justice within our society. The purpose of this paper is to propose that the legal clinical model be revamped to train law students to become not just lawyers, but agents

1 Professor Nekima Levy-Pounds is the Director of the Community Justice Project (CJP) and Artika Tyner is a Clinical Law Fellow at the University of St. Thomas, School of Law, Minneapolis, Minnesota. Through the CJP, students can integrate the University of St. Thomas' mission into their Clinic experience as they work for justice and reconciliation. Following the sub-Saharan African ideology of Ubuntu, clinical students focus on creating systemic changes that will further humanitarian goals. The CJP strives to build bridges with community stakeholders and to work collaboratively to address problems in distressed communities. Students conduct research and propose practical solutions to longstanding injustices, such as police brutality and racial disparities in the criminal justice, educational and juvenile justice systems.

2 See Clinical Anthology: Readings for Live Client Clinics (Susan L. Kay et al. eds., Anderson Pub. Co., 2003) (clinic programs were introduced during the late $1960 \mathrm{~s}$ as an alternative to case-book law teaching).

3 Clinic models offer the skills based training necessary for the practise of law. Many clinics provide an opportunity for students to engage with real clients in role as legal representatives. "Under the supervision of an attorney, students enrolled in clinics have actual clients with real problems. Many clinics provide legal assistance to those who cannot otherwise afford an attorney, helping to solve landlord-tenant disputes, settle domestic conflicts or defend against criminal charges. In these cases, the students often represent their client's interests in a courtroom or at an administrative hearing. Other clinics are non-litigation in nature. In these clinics, student may work in areas such as community economic development, small business representation, appellate advocacy and legislative advocacy." How to get Real World Experience while in Law School, Newsweek, http://ejwguide.newsweek. com/chapters/hands-on.htm (last visited May 30, 2008). 
of social change. ${ }^{4}$ Although we hope this article will be of relevance to a broad international audience, the critique focuses mainly on legal education in the United States.

In order to more effectively train the next generation of leaders and advocates for social justice, law schools and other academic institutions must be willing to implement innovative teaching strategies that offer hands-on learning experiences and opportunities to more fully develop problem solving skills. ${ }^{5} \mathrm{~A}$ recent report entitled, "Educating Lawyers: Preparation for the Profession of Law," need for a more integrated approach to law teaching that draws upon innovative teaching techniques: The premise being that "legal education should seek to unite the two sides of legal knowledge: formal knowledge and experience of practice." While the legal clinical model has been utilized in many law school programs to teach law students practical skills, this model could be taken to the next level by implementing an overt focus on social justice lawyering. Clinic professors may prepare law students to address the needs of under-served communities by incorporating the sub-Saharan African philosophy of Ubuntu into the course curriculum. Ubuntu draws upon a relational worldview by recognizing the universal bonds and sense of interrelatedness of humanity ${ }^{7}$ by challenging lawyers to use their legal skills to promote social good and further humanitarian goals. Archbishop Tutu characterizes a person with Ubuntu as "available for others and to know that you are bound up with them in the bundle of life, for a person is only a person through other persons. And so we search for this ultimate attribute and reject ethnicity and other such qualities as irrelevancies." ${ }^{8}$ By applying the principles of Ubuntu, law students will be prepared to serve as agents of social change in their local communities and society at large.

Part I of this Article will outline the pressing need to empower law students to lead and persevere in the face of societal injustice. It will also provide a framework for promoting social justice by

4 The philosophy of training students to be agents of social change is based upon the instructional pedagogy of Dean Charles Houston. Dean Houston trained his students to use the law as an instrument to further social justice. He taught that "a lawyer's either a social engineer or he's a parasite on society." A social engineer was a highly skilled, perceptive, sensitive lawyer who understood the Constitution of the United States and knew how to explore its uses in the solving of "problems of ... local communities" and in "bettering conditions of the underprivileged citizens." Charles Hamilton Houston Institute, http://www.charleshamilton houston.org (last visited Feb. 5 2008).

5 The Clinical curriculum should challenge students to think critically and ethically while promoting social good. Professor Gerald Lopez characterizes the traditional legal curriculum as unchallenging. "Unchallenged by a place that had no idea about, and apparently little interest in, how to draw on interdisciplinary knowledge that bears on both understanding and doing something to fight social, political, economic, and legal marginalization." Gerald P. López, Rebellious Lawyering: One Chicano's
Vision of Progressive Law Practice, 5 (Westview Press 1992).

6 Educating Lawyers: Preparation for the Profession of Law, The Carnegie Foundation for the Advancement of Teaching, (Jossey-Bass, 2007) http://www.carnegiefoundation.org/files/elibrary/E ducatingLawyers_summary.pdf (last visited June 9, 2008).

7 Former President Nelson Mandela recognized the inevitability of "mutual interdependence" in the human condition that "the common ground is greater and more enduring than the differences that divide." Anders Hallengen, Nelson Mandela and the Rainbow of Culture, http://nobelprize.org/ nobel_prizes/peace/articles/mandela/index.html (last visited June 12, 2008).

8 Desmond Tutu, The Rainbow People of God: The Making of a Peaceful Revolution, 125 (Doubleday 1994). 
integrating principles of servant leadership and Ubuntu into the legal clinical model curriculum. ${ }^{9}$ Part II will offer a model curriculum and practical methods for using the legal clinical model to empower law students to lead and serve in under-served communities. Part III will provide examples of student-led initiatives that have promoted social justice in under-served communities. Part IV concludes the findings of this Article that the legal clinical model may be further developed to train future leaders and promote the furtherance of social justice.

\section{Part I. The Call to Servant Leadership and Application of Principles of Ubuntu}

In order to take the legal clinical model to the next level, law schools must be willing to go in a new direction. The current structure of legal education, at least in the United States, is woefully inadequate in developing lawyers whose focus is on achieving social justice and who are passionate about using the law as a tool to address the needs of the poor and the disenfranchised. This notion of servant leadership is markedly absent from the law school curriculum, even though it helps to form the basis of the ideal attorney/client relationship. Based upon Robert K. Greenleaf's essay entitled Servant as Leader, a servant leader is one who places the needs of others above his own needs. ${ }^{10} \mathrm{He}$ describes the process of servant leadership that "begins with the natural feeling that one wants to serve, to serve first. Then conscious choice brings one to aspire to lead." 11 The key priority is serving first and then leading. The lawyer as servant leader acts with humility and respect by simply asking the questions: How can I be of service? How can I, as an attorney, utilize my gifts and talents to serve communities and further the legal profession's commitment to service?

Notable examples of lawyers as servant leaders include, former President of South Africa Nelson Mandela ${ }^{12}$ and Justice Thurgood Marshall. ${ }^{13}$ Both men exemplified the moral courage, strength and passion for social justice ${ }^{14}$ that members of our profession should aspire to cultivate. These

9 Principles of servant leadership and Ubuntu create a framework for developing a relational worldview. This worldview provides law students with the tools to promote "social solidarity." "Achieving social solidarity means that members of the society once again begin to recognize each other as fellow human beings and begin to share a concern in the common welfare and well-being of each other. Social Solidarity makes sense because only by ensuring the security, safety and well-being of other people can we hope to secure our own security, safety, and wellbeing." Tim Murithi, African Approaches to Building Peace and Social Solidarity, 6(2) African J. on Conflict Res. 9, 14 (2006).

10 Robert K. Greenleaf, The Servant as Leader, 7 (Greenleaf Center, 1991).

11 Robert Greenleaf, Robert K. Greenleaf Center for Servant-Leadership at http://www.greenleaf.org (last visited Mar. 12, 2008).

12 Nelson Mandela studied law at the University of the Witwatersrand and obtained his law degree from the University of South Africa in 1942. Mandela spent 27 years in prison due to his efforts to dismantle the South African apartheid. Nelson Mandela, One Nation, One Country, xi (PhelpsStokes Institute for African, African-American, and American Indian Affairs, 1990).

13 Thurgood Marshall was instrumental in the drafting of the constitutions of Ghana and Tanzania. He was also counsel for the landmark case of Brown v. Board of Education, which led to the desegregation of U.S. schools. In 1967, Thurgood Marshall was appointed to the U.S. Supreme Court. Thurgood Marshall Supreme Court Justice, Biography, http://chnm.gmu.edu/courses/122/hill/ marshall.htm (last visited Mar. 12, 2007).

14 Establishing a working definition of social justice is an integral part of examining the role of attorneys and evaluating teaching methods. Social justice has been characterized as the process of remedying oppression, which includes "exploitation, marginalization, powerlessness, cultural imperialism, and violence." Pamela Edwards \& Sheila Vance, Practice and Procedure: Teaching Social Justice through Legal Writing, 7 Berkeley Women's L.J. 63 (2001). 
servant leaders fought relentlessly in the trenches for justice, peace, and the furtherance of humanitarian goals by waging combat through the use of their legal skills.

This idea of servant leadership is in stark contrast to the implicit and sometimes explicit message that is often given in a law school environment, where one's own need to pay off student loans and to live a comfortable lifestyle is placed above the importance of using one's legal talents to benefit those who face oppression and disenfranchisement. Because of the failure of law schools to explicitly articulate the responsibility to use the law as a tool to help those less fortunate, law students, generally speaking, abandon this responsibility when it conflicts with their desire for worldly comfort. Even when law students are passionate about social justice, they are encouraged to work within the parameters that have already been defined within the profession, such as serving as a public defender or legal aid lawyer, even though opportunities to correct wide-scale legal injustices are often diminished within these positions, primarily due to limited resources and time constraints. Such wide-scale legal issues may include racial disparities within the adult and juvenile criminal justice systems, the prevalence of police misconduct and brutality in poor communities of color, and the reintegration challenges facing people with criminal histories. Although poor communities of color are disparately impacted by these issues, they are least likely to receive adequate assistance in addressing such problems.

The severity of the problems facing poor communities, coupled with the funding and resource issues faced by public service organizations, means that law schools are in a prime position to use legal talent and resources to resolve some of our nation's most challenging problems. Law schools in general, and law school clinical programs in particular, have the ability to help shape legal minds and to prepare law students to serve the community in a more holistic manner.

In addition to strengthening the leadership capabilities of law students, there is also a dire need to foster a more meaningful commitment to public service. Through the study of Ubuntu, law students are encouraged to focus on ministering to the needs of others through the utilization of their legal skills which reinforces the concept of servant leadership by focusing on "serving first." The study and application of principles of Ubuntu requires a shift in cultural perspectives related to the concept of community from the Western ideas of individual autonomy ${ }^{15}$ to the focus on the collectivist and communal nature of African culture. ${ }^{16}$ In relation to the practice of law, Ubuntu focuses on the "interrelatedness" of the human experience that requires each person to use his/her gifts and talents to better society. The concept of Ubuntu was also encompassed in Rev. Martin Luther King, Jr.'s vision of “interrelatedness.” King characterized life as follows: "In a real sense all life is inter-related. All men are caught in an inescapable network of mutuality, tied in a single garment of destiny. Whatever affects one directly affects all indirectly." 17

15 Professor Dirk Louw characterizes Western society as competitive and individualistic. "Individual interest rules supreme and society or others are regarded as nothing but a means to individual ends. This is in stark contrast to the African preference for co-operation, group work or shosholoza ("work as one," i.e. team work)." Dirk Louw, Ubuntu and the Challenges of Multiculturalism in post-apartheid South Africa, http://www.phys.uu.nl/ unitwin/ ubuntu.doc (last visited Sept. 1, 2008).

16 According to Human Rights Advocate Ahmed Sirleaf II, "Ubuntu focuses on the essence of commonality that binds all together." Sirleaf suggests that cultures began to globalize; hence by applying Ubuntu to clinical education African philosophical theories will be transported across national borders and cultural groups to promote social justice. Telephone Interview with Ahmed Sirleaf II, The Advocates for Human Rights Program Associate, Liberian Truth and Reconciliation Commission (June 4, 2008).

17 Martin Luther King, The American Dream, http://www.indiana.edu/ ivieweb/mlkad.html (last visited Sept, 1, 2008). 
The principles of Ubuntu encompass the sense of "interrelatedness" that addresses the societal need for love, peace, and justice. By embracing principles of Ubuntu, law students are trained to recognize the power that a law degree provides in creating access to justice, protecting the rights of those marginalized, and shaping public policy. According to Archbishop Desmond Tutu:

... a person with Ubuntu is open and available to others, affirming of others, does not feel threatened that others are able and good, for he or she has a proper self-assurance that comes from knowing that he or she belongs in a greater whole and is diminished when others are humiliated or diminished, when others are tortured or oppressed. ${ }^{18}$

The clinic course curriculum can provide law students with the tools to become an agent of social change and cognizant of their responsibility to work towards the greater good of society. This responsibility requires being an advocate for justice, fairness, and equity. The 1997 South African Governmental White Paper for Social Welfare asserts:

The principles of caring for each other's well-being... and a spirit of mutual support...Each individual's humanity is ideally expressed through his or her relationship with others and theirs in turn through a recognition of the individual's humanity. Ubuntu means that people are people through other people. It also acknowledges both the rights and responsibilities of every citizen in promoting individual and societal well-being. ${ }^{19}$

By incorporating the principles of Ubuntu into the clinic curriculum, law students are reminded that they can be the change they hope to see in the world.$^{20}$ Historically, lawyers have been pioneers in leading social change in various arenas: namely, political, social, and economic. Experience has shown us that, "the law can be an incredible vehicle for social change and lawyers are at the wheel." 21 Our law degrees provide us with the ability to create social change through our power to build, restore, and transform communities. Legal educators play an integral role in giving more focused attention "to the actual and potential effects of the law school experience on formation of future legal professionals." 22 Clinic professors have the opportunity to guide law students in the process of becoming agents of social change.

With these ideals in mind, we created the Community Justice Project ("CJP") at the University of St. Thomas School of Law in Minneapolis, Minnesota. Throughout this paper, we will provide a brief description of the CJP, the curriculum that we created, along with a synopsis of some of the current initiatives that we have implemented through the CJP. We believe that the CJP serves as an ideal model which can be replicated by other clinic programs and community outreach organizations to develop lawyers into servant leaders and effective agents of social change.

18 Tutu, supra note 10 at 125.

19 Department of Welfare, Private bag X901, Republic South Africa, August 1997, http:/www.welfare. gov.za/Documents/1997/wp.htm (last visited June 19, 2008).

20 "We need to be the change we wish to see in the world." Mohandas Gandhi as quoted in "Arun Gandhi Shares the Mahatma's Message" by Michel
W. Potts, in India - West [San Leandro, California] Vol. XXVII, No. 13 (Feb. 1, 2002) p.A34.

21 "Hillary Clinton on a Law Career in Public Service," Newsweek, http://www.msnbc.com/id/ 14269839/site/newsweek/print/1/displaymode/1098/ (last visited June 7, 2007).

22 Carnegie Report at 10. 


\section{Part II. Instructional Practices: CJP Class Readings, Group Discussion, Observation}

An integral step in preparing law students to become agents of social change is to deliberately and strategically incorporate principles of social justice into the legal clinical curriculum and programming. Recently, the Carnegie Report highlighted this need by identifying that the key challenge of legal education is "linking the interests of legal educators with needs of legal practitioners and with the public the profession is pledged to serve." ${ }^{23}$ Clinic professors can aid in this training by engaging law students in ongoing dialogue about social justice issues, exposing students to the diverse life experiences of community members, and encouraging them to use the law as a tool to promote justice and social change.

With these goals in mind, the curriculum of the CJP was designed to be thought-provoking, challenging, and enlightening. The training materials are used to transform the students into agents of social change during their clinical experience and beyond.

\section{A. CJP Approach to Community Lawyering}

The CJP curriculum is based upon a model of community lawyering that focuses on working collaboratively within an interprofessional setting, empowering marginalized populations, and providing leadership training for aspiring attorneys. The community lawyering model focuses on holistic advocacy. Further, the community lawyer addresses the root cause of the social problems in under-served communities; instead of focusing merely on resolving a legal issue. The model is a client-centered approach that answers questions such as: What support is needed to remedy the legal issue and promote community-building? How can similar circumstances be prevented in the future? How can the community benefit from an interprofessional model of partnership with counseling services provided by social work and psychology professionals?

These principles are taught through a variety of course materials, which include historical texts, local media sources, and philosophical readings. The diverse array of readings provides students with the tools to effectively advocate at a grassroots level, one community at a time. At its core, the CJP encourages students to reappraise what it means to be a lawyer.

The process of community lawyering used by the CJP begins with an invitation from the community. The community should welcome the community lawyer into the community. CJP received its invitation from the St. Paul National Association for the Advancement of Colored People (NAACP) to address quality of life issues of the African American community. The next step is the immersion process which uses the principles of ethnography. During this process, the community lawyer becomes a participant observer. The community lawyer must become immersed in the community so gaining a deeper understanding of the root causes of the legal and social issues. For instance in our Clinic, CJP students gain hands-on experience by reading a community newspaper, court observations, organizing community town hall forums, and spending time at a local coffee shop meeting with community members. Through these experiences, our students gain cross-cultural competence skills and establish a positive rapport with the community. The next step takes place during the problem solving phase. In this phase, the community lawyer works with the community in planning steps to achieve the community's goals. The key focus is on

23 Carnegie Report at 4. 
collaboration. The community lawyer uses a variety of skills at this stage such as fact investigation, writing as advocacy, critical thinking, reflective listening, negotiation, and mediation. The final stage is implementation. This is the process of empowering the community. The community lawyer works with the community to help it realize its power and protect its legal rights. Although the community lawyer performs a key galvanizing role, overall, this is a community-led initiative.

\section{i. Utilization of an Interprofessional Approach}

Traditionally, lawyers work independently to resolve legal challenges that clients face. However, each client may also have a myriad of extra-legal issues ranging from psychological to social issues. The interprofessional model can offer a paradigm shift by focusing on holistic lawyering. "Holistic lawyering is analogous to holistic medicine. Just as a holistic medical provider treats all aspects of a patient suffering from a particular medical illness, a holistic lawyer addresses the whole person and not just a client's particular legal issue." 24 The practice of holistic lawyering requires collaboration with other problem-solvers in various professional roles rather than overlooking the benefits of an interprofessional approach. ${ }^{25}$

This is the case especially when working with under-served communities in high-need areas since a legal problem may also be coupled with a need for case management ${ }^{26}$ due to the absence of economic development and revitalization efforts in the community. Psychological services ${ }^{27}$ may also be needed based upon traumatic life experiences suffered from living life in the margins of society. CJP students work collaboratively with psychology and social work students as they strive to meet the needs of underserved communities while gaining practical real-world experience and cultural competency skills. ${ }^{28}$ One such example is the joint efforts of social work and CJP students in addressing the achievement gap in the local public school system. Students served on an advisory board that brainstormed methods to improve the quality of education received by African-American students in Saint Paul, Minnesota and methods to bridge the achievement gap.

\section{ii. Empowerment of Communities}

Agents of social change must also empower the communities served by aiding in the fight against injustice. Community members should play a fundamental role in addressing the community's needs. This goal is obtainable when attorneys become sensitive to the needs of the community and overcome the tendency of taking over the community's problems. CJP students are encouraged to

24 Innovations in the Delivery of Legal Services: Alternative and Emerging Models for Practicing Lawyer, American Bar Association (2002).

25 López, supra note 5 at 37.

26 Social Work Services provides comprehensive client case management. Case managers develop extensive knowledge on a variety of issues affecting clients, such as housing, transportation, food support, linkages to English language classes, job training and other education programs. Case managers provide much needed emotional support to clients embroiled in difficult legal issues. University of Saint Thomas Interprofessional Center available at http://www.stthomas.edu/ ipc/about/IPC_Collaboration.html. (last visited
July 1, 2008).

27 Psychological assessments are a frequent request from both external referral sources and the Center's legal professionals. Request range from a simple screening to a comprehensive psychological report to be used for treatment plan development, educational, and vocational planning or for informing a legal process. Id.

28 The Community Justice Project is a part of the Interprofessional Center for Counseling and Legal Services. This is a joint effort by the School of Law, the Graduate School of Professional Psychology (a division of the College of Applied Professional Studies), and the University of St. Thomas/College of St. Catherine School of Social Work. Id. 
prevail over this inclination by being responsive to the needs of the community. The role of the community lawyer and common lessons and pitfalls are discussed and examined through the study of Lucie White's To Learn and Teach: Lessons from Driefontein on Lawyering and Power. ${ }^{29}$

The process of community empowerment through social justice lawyering is exemplified in Professor White's case study of the Driefontein community. ${ }^{30}$ The study focused on the process of a South African community that successfully organized to combat subordination with the aid of a lawyer and community organizer who followed a model of change-oriented lawyering. ${ }^{31}$ Within a change-oriented lawyering model, a lawyer engages in a mutual learning process while helping a community to appreciate the full measure of its own power. ${ }^{32}$ The learning process began when the lawyer received an invitation from the village to aid in resisting government mandated removal from its community to designated homelands. ${ }^{33}$

The lawyer and organizer utilized an interprofessional approach in addressing the community's needs. Their goal was to empower the community to overcome both the current and even future challenges. "The villagers did not hand their problems over to the lawyer, who then acted for them. Rather the lawyer and organizer worked with the villagers to help them gain power." 34 One such example is when the organizer assisted the community in creating social services. This included the creation of legal and health clinics to improve the accessibility of social services. The community also used performance arts as a form of cultural expression and political resistance. The village women performed a play about the proposed removal through African movement and dance. This example illustrates how the lawyer and organizer helped the community members identify and cultivate their strengths. ${ }^{35}$

As illustrated in the case of Driefontein, lawyers in partnership with other professionals can play an integral role in empowering communities. Once a community has realized the full potential of its power, community members are likely to be prepared to address future social, political, or legal matters more effectively.

\section{iii. Leadership and Problem Solving Skills Development}

The foundations of leadership principles are developed through the reading of The Servant as Leader, related lecture, and classroom discussions. During this lecture, students are challenged to identify the characteristics of the servant leader and discover ways to incorporate the principles of servant leadership into their professional identities. ${ }^{36}$ Students also complete a servant leadership inventory which aids them in identifying their leadership capabilities and then working to develop those qualities. ${ }^{37}$ Leadership principles that are outlined in Paulo Friere's Pedagogy of the Oppressed are also discussed during class and incorporated into the legal training. For example, CJP students draw upon the lessons learned by Freire as he fought to increase access to education for oppressed

291988 Wis. L. Rev. 699 (1988).

$30 \mathrm{Id}$.

$31 \mathrm{Id}$.

32 Id. at 767.

33 Id. at 706 .

34 Id. at 737.

35 Id. at 725 .
36 Sample discussion questions include, but are not limited to: Who is the servant leader? How can the leadership crisis be characterized? What are practical ways to be a servant leader? Does legal education foster leadership growth and potential?

37 University of Nebraska, Becoming a Servant Leader: Do you have what it takes? http://www.ianrpubs.unl.edu/epublic/live/g1481/bui 1d/g1481.pdf (last visited Feb. 5, 2008). 
groups in Brazil. ${ }^{38}$ One key lesson that CJP students learn is that they must engage in a mutual learning process ${ }^{39}$ in order to effectively serve the needs of the community. According to Freire, "revolutionary leaders cannot think without the people, nor for the people, but only with the people." 40 This mutual learning process can be enhanced by building trust within the community and respecting its members. "The people must find themselves in the emerging leader, and the latter must find themselves in the people." ${ }^{41}$ Freire also highlights the importance of engaging in dialogue with community members in order for lawyers serving as agents of social change to develop a shared vision for the future. "Dialogue is the encounter between men, mediated by the world, in order to name the world." 42 Through the dialogue process, relationships can be formed between community members and lawyers. The foundation of these relationships is recognizing the interrelatedness of the human experience and understanding that "common ground is greater and more enduring than the differences that divide." 43

Integral to the training of agents of social change is the development of creative problem solving techniques. ${ }^{44}$ Professor Levy-Pounds' motto is "think outside the box and reshape it." In essence, students must dare to be bold in the face of injustice and show commitment to creating equal access to justice. One such example is the exploration and practical application of restorative justice principles. CJP students are required to read Howard Zehr's The Little Book of Restorative Justice as a foundational text on the theory of restorative justice. ${ }^{45}$ This text challenges students to contrast the punitive nature of the traditional American criminal court system with the transformative power manifested through various restorative justice models. ${ }^{46}$ After reading the text, CJP students are able to identify the benefit of restorative justice practices of "putting things right" by focusing on the harm to and needs of all participants (victims, offenders, and community

38 "Freire was a pioneer in promoting the universal right to education and literacy as part of a commitment to people's struggle against oppression." Paulo Freire, Cultural Action for Freedom, 1 (Harvard Educational Pub. Group; 2000 ed. Edition, Penguin, 2006). Freire sought to empower those who were illiterate by enabling them to become oriented with the world around them through civic engagement. This orientation process recognized their humanity through the integration into the very fabric of society and gave them the freedom to change the future. Id. at 14 .

39 "They must understand how to educate those with whom they work, particularly about law and professional lawyering, and, at the same time, they must open themselves up to being educated by all those with whom they come in contact, particularly about the traditions and experiences of life on the bottom and at the margins." Lopez, supra note 5, at 37.

40 Paulo Freire, Pedagogy of the Oppressed, 112 (New York, 1970).

41 Id. at 144.

42 Id. at 69.

43 Anders Hallengren, Nelson Mandela and the Rainbow Culture, http://nobelproze.org/cgi-bin (last visited June 25, 2008).
44 An integral element of problem solving is creating a strategic plan of action. When reflecting upon his prior chairmanship of the Washington State Bar Association, Bill Gates Sr. highlights the need for lawyers to develop problem solving skills. "The essence of civil work is problem-solving: the city needs a zoo, our schools need to pass a levy, foster children deserve a better shake. There are thousands of problems, virtually none of which are going to be rectified without organized citizen involvement." "Bill Gates Sr. on Public-Service Law, Newsweek, http://www.msnbc.msn.com/id/15385956/site/news week/ (last visited June 5, 2007).

45 CJP students are also required to read Kay Pranis, Face to Face: Spaces for Reflective Community Dialog to gain a deeper understanding of the healing power of restorative justice, specifically sentencing circles, http://www.corr.state.mn.us/rj/publications/facetofa ce.htm (last visited Feb. 5, 2008).

46 Restorative justice takes a holistic approach by addressing the needs of victims, encouraging offenders to take responsibility, and involving those affected by an offense in the process. Howard Zehr, The Little Book of Restorative Justice (Good Books, 2002). 
members), addressing obligations of each, using an inclusive and collaborative process, and involving all stakeholders. ${ }^{47}$ CJP students also receive hands-on experience in applying these principles. Through the Restorative Justice Project, ${ }^{48}$ CJP students are able to help create a sense of community, bring all participants together and extend an invitation for dialogue and healing.

CJP students also participate in restorative justice circles as community members. In this role, CJP students serve as community participants by expressing the concerns of the community related to promoting social welfare, upholding civil rights and liberties, and ending police brutality. The benefit of students' involvement in circle processes are numerous and far-reaching.

\section{B. Community News - Insight News}

In order to become more culturally competent and to gain a deeper understanding of the needs of the community being served, CJP students are required to read the weekly edition of Insight News and discuss the current events in class. Insight News is a local journal for community news, business, and the arts. The mission of Insight News is "to inform, instruct and inspire." 49 Insight News lives its mission by offering a wide array of articles that identify and address the diverse needs of the African American community in the Twin Cities. The weekly edition includes articles ranging from historical perspectives on race to emerging civil rights issues that impact the local African American community. ${ }^{50}$

During weekly class discussions, students share the stories in Insight News that caught their attention. One such example was Insight News' coverage of the national mortgage crisis. ${ }^{51}$ Insight News covered this story from the onset of the crisis by offering firsthand accounts of the impact of foreclosure on the community, interviewing legislators, and tracking the related predatory lending bill. ${ }^{52}$ These stories enabled students to gain a deeper understanding of the mortgage crisis phenomenon. It also inspired students to initiate their own efforts in the community. CJP students, along with student representatives of the Lawyers' Council for Social Justice ${ }^{53}$ canvassed communities in North Minneapolis (which has a high concentration of poor African-Americans) and provided information on protection against predatory lending and foreclosure. ${ }^{54} \mathrm{CJP}$ students also played an active role in hosting and participating in a law school-sponsored forum on mortgage fraud. ${ }^{55}$

47 Id. at 19.

48 CJP students have played an integral role in the formation of a restorative justice project. In collaboration with the Saint Paul City Attorney's Office and Saint Paul Police Department, a restorative justice project has been created that will address the racial disparities in the charging of Obstructing of Legal Process (OLP). This project created an opportunity for a dialogue related to community/police tension and offers the possibility of aiding in the healing of these relationships.

49 Insight News, (Minneapolis) available at http://www.insightnews.com/ (last visited Feb. 5, 2008).

50 Examples include: Public Hearing on the Enforcement of Human Rights and Civil Rights and Two Powerful Images that Can Free your African Mind.
51 ACORN calls for freeze on foreclosure, Insight News (Minneapolis), Aug. 31, 2007.

52 Bush proposals to help those at risk of home loans foreclosure needs a dose of scrutiny, Insight News (Minneapolis), Sept. 17, 2007.

53 This group was started in 2006 by a first year law student, Sonia Laird, at the University of St. Thomas School of Law.

54 Insight News also published articles that focused on the needs of the North Minneapolis community. Conversations on Managing the Mortgage Crisis in North Minneapolis, Insight News (Minneapolis), Feb. 8, 2008.

55 See Mortgage Fraud Forum, University of Saint Thomas School of Law, http://www.stthomas.edu/ethicalleadership/research /conferences/mortgage $\% 20$ fraud $\% 20$ forum 1 .html 


\section{Small Group Discussions and Setting Ground Rules}

The CJP course curriculum is designed to be discussion-based and interactive. In order to reach this goal, students must feel free to express themselves in a safe and respectful learning environment. This sense of safety is created by setting ground rules for discussion. The first rule is being respectful by acknowledging that each member of the group has a different "life lens," which is shaped by personal life experiences, faith journey, culture, heritage, upbringing, and/or socioeconomic status. In addition, everyone must trust that the ideas and opinions expressed in class are meant to create a deeper understanding, promote development, and foster transformation and growth. All members of the class must also agree that the class discussion will be kept confidential in order to build trust and strengthen interpersonal relationships.

It is also paramount that students express a willingness to grow and explore.

For instance in the Marginalized Populations class series, ${ }^{56}$ students examine the social construction of race in America and the history of the civil rights movement. These class discussions are typically very intense since students are addressing issues like institutionalized racism, poverty, and human rights violations.

This leads to the next rule that students must also be open to being challenged and stretched in their ways of thinking. Collectively, CJP students embark on a learning journey together and must be willing to explore differing views. Personal attacks are not allowed, but ideas are challenged and questioned. Through this dialogue process, CJP students grow immensely and their worldview evolves as they become agents of social change.

\section{Court Observations}

We have found that nothing is more invaluable than gaining firsthand experience in the community being served. CJP students are required to complete five hours of court observation, which includes three hours of adult criminal court and two hours of juvenile court. They observe court room dynamics, examine procedural fairness, and collect demographical information. After their visit, students draft and submit a memorandum related to their experiences. Students are also encouraged to perform a police ride-along, which consists of accompanying police officers as they perform routine duties in the local community. In addition, students are required to attend and observe a community conferencing session. This allows students to gain a deeper understanding of restorative justice practices. ${ }^{57}$

56 The Marginalized Populations lecture is a two-part class series. Marginalized Populations Part One focuses on cultural competence in the practice of law. This includes the examination of gender, ethnic, cultural, and socioeconomic classifications. The class reading consists of In God's Image, Pastoral Letter on Racism authored by Archbishop Harry J. Flynn, http://www.osjspm.org/racism.htm, Racial Disparity Initiative- Council on Crime and Justice, http://www.crimeand justice.org/Pages/ Publications/Articles/INCREASING\%20DIVERSI TY_COMMENTARY_06_10_02.pdf and the viewing of Poverty USA Video clip, http://www.nccbuscc.org/cchd/povertyusa/tour2.htm Marginalized Populations Part Two focuses on the needs of juveniles in distressed communities. The class readings consist of Building Blocks for Youth, http://www.buildingblocksforyouth.org/advocacygu ide.html.

57 The community conferences are facilitated by Restorative Justice Community Action, Inc., online at http://www.rjca-inc.org (last visited Jun. 19, 2008). 


\section{E. Reflective Essays}

Educational theory supports the notion that the formula for learning begins with experience plus reflection. The process of learning is about "action, reflecting, adjusting and acting again." 58 CJP students are encouraged to become reflective learners. Throughout the semester, students complete reflective exercises, which include drafting essays, journaling, and participating in small group discussions. This process of reflection allows students to discover methods for merging their personal identity and professional identity without the need to compartmentalize views and perspectives. "Using alternative approaches in legal writing teaches the value of both the legal voice and the personal voice, especially the voice of 'outsiders'." 59 As both the legal and personal voices emerge, students are encouraged to write reflective essays or journal entries that explore their worldview as it evolves throughout their educational and professional development. This approach enables students to identify how their life experiences have shaped the way that they view the concept of social justice. Additionally, students are encouraged to evaluate whether this view has changed based upon class discussions, volunteer experience, and participation in clinical programming.

\section{Part III. Description of Current CJP Initiatives}

Through the CJP, we have implemented a number of community-based initiatives that seek to address some of the underlying issues that impact poor communities of color. Some of our current initiatives include the development of a reintegration and prevention program for AfricanAmerican boys and men in Saint Paul, an evaluation of the civilian review complaint process for alleged victims of police misconduct and brutality, and a community awareness program to educate youth and their parents about the impacts of involvement in the juvenile justice system. Each program is unique and requires the cooperation of local city government, the police department, the city attorney, the public school system, and the community in order to be successful. There follows a brief description of the scope of each project and its expected outcome.

\section{A. Reintegration Initiative: Brotherhood Inc.}

Our goal is to create a reintegration program that will assist young people from poor communities in becoming upwardly mobile. We have had several meetings with the Saint Paul City Attorney's Office, the Saint Paul Mayor's office, a representative from the Saint Paul Police Department, and the Saint Paul NAACP regarding the disparate rate of involvement of poor African-American youth within the juvenile justice system. The decision was made to go beyond discussing these issues and to actually do something that will benefit the youth in question, and society at large. The CJP agreed to take the lead in preparing a proposal for consideration by stakeholders.

The first step was to identify an appropriate program model. We chose Homeboys Industries out of Los Angeles as the model because of the high quality and effectiveness of the program. In order to gather accurate information, two students from the CJP flew to Los Angeles, California to visit

58 Nelson Mandela Institute, available at http://www.mandelainstitute.org.za/liberation.aspx (last visited June 25, 2008).
59 Mahoney, Calmore, Wildman, Teachers' Manual to Accompany Social Justice: Professionals, Commuities and Law Cases and Materials 4 (West Publishing Company, 2003), citing Edwards and Vance. 
Homeboy Industries and to interview members of their staff. ${ }^{60}$ Following their visit, the students prepared an extensive report examining the feasibility of implementing a similar program in Saint Paul. In February, 2008, the proposal was submitted to the Mayor of Saint Paul, along with representatives from various foundations within the state of Minnesota. This was the birth of Brotherhood Inc., a comprehensive reintegration and prevention program that will offer a social enterprise and integrated social services for young African-American boys and men who have had contact with the criminal justice system. Most recently, the CJP has formed a partnership with a local neighborhood development corporation to bring the vision of Brotherhood, Inc. to fruition.

\section{B. Evaluation of Civilian Review Process}

Based upon concerns raised by the Saint Paul NAACP and members of the African-American community in Saint Paul, the CJP decided to examine the complaint process that is used to evaluate grievances by alleged victims of police brutality and misconduct. The goal of the project is to uncover hidden biases and gaps in the process that need to be addressed in order to ensure that justice occurs for those filing complaints. CJP students interviewed members of the Police Civilian Review Commission and examined the appropriateness of the forms that are used to report grievances for clarity and readability, as well as the means by which the public may obtain complaint forms. The results of the students' inquiry, research and investigation was a written report that includes recommendations for improving the process and increasing access to justice. CJP students also prepared sample forms for adoption by the Police Civilian Review Commission to both simplify and clarify the process.

\section{Community Awareness Program (CAP)}

Recent reports indicate that children of color are substantially over-represented in the juvenile justice system. ${ }^{61}$ Once children become involved in the juvenile justice system, there are a number of collateral consequences in place which prevent both their successful reintegration into society and, for those living in under-served communities, their opportunities for upward mobility. In response to this growing issue, the CJP set out to create awareness amongst youth and their families in the Twin Cities by developing the curriculum for the Community Awareness Program (CAP).

Through CAP, CJP students go out to local public schools with a high concentration of poor children of color and into the community to conduct presentations related to children and the law. The scope of the presentations includes the impacts of truancy violations, petty theft, school fights, and loitering on one's ability to find future employment, housing, and to gain college admission. Children and their parents are also advised on current trends in the law, such as: how a youth in possession of a BB gun may be charged with a felony; and an explanation of the lifetime bar on obtaining certain types of employment licenses through the Minnesota Department of

60 CJP students, Dan Olson and Luis Verdeja, visited Homeboy Industries on Nov. 1, 2007. They conducted interviews of staff members, Peer Navigators and Homeys. They also toured the Homeboy Industries and Homegirl Café.

61 The 2007 America's Cradle to Prison Pipeline Report highlights the following statistics: A Black boy born in 2001 has a 1 in 3 chance of going to prison in his lifetime; a Latino boy a 1 in 6 chance; and a White boy a 1 in 17 chance. Black youth are about four times as likely as their White peers to be incarcerated. Black youth are almost five times as likely to be incarcerated as White youth for drug offenses. Children's Defense Fund, available at http://www.childrensdefense.org/site/DocServer/CP P_report_2007_foreword.pdf?docID $=5062$ (last visited Jun. 19, 2008). 
Human Services for commission of certain types of crimes. The goal of the project is to create awareness amongst children and families who, statistically speaking, are more likely to come into contact with law enforcement. Our hope is that preventative education, such as is offered through CAP, ${ }^{62}$ will result in fewer children becoming involved in the juvenile justice system.

As illustrated above, our goal is to use the law as a tool to effectuate change on behalf of underserved communities. Many of the residents of these communities are over-represented within the criminal justice system, yet are under-served and often receive inadequate legal assistance. ${ }^{63}$ Through the CJP, we strive to find gaps within the system that are detrimental to the community and to offer recommendations for improvement.

Law students benefit immensely from their involvement in CJP initiatives as they are encouraged to "think outside of the box," engage in problem-solving, collaborate with various stakeholders in local government and the community, participate in meetings of grassroots and civil rights organizations, and use their legal skills to benefit those from disadvantaged backgrounds. Working on CJP projects has the added advantage of empowering law students to understand the importance of giving back to the community and the great responsibility that comes with having an advanced degree - a responsibility that is often under-emphasized throughout the law school experience. Finally, by meeting with, collaborating with, and speaking on behalf of the community, law students become more culturally competent and able to interact with people from a variety of racial and ethnic backgrounds and socio-economic levels.

\section{Part IV. Conclusion}

Due to the pervasive presence of societal injustices and the threat to human and civil rights, the time has come for the legal clinical model to do more than just teach students to become lawyers, and begin training them to become agents of social change. This requires innovative teaching strategies that focus specifically on the furtherance of social justice initiatives. A curriculum that focuses on principles of Ubuntu should be used as the foundation for developing each student's leadership capabilities and reinforcing a more meaningful commitment to service. Ubuntu "affirms a higher notion of what it means to be human. It suggests that all people, and communities of people, are a source of power and creativity. It is an affirmation of the possibilities of the human spirit, and the power of authentic human-to-human engagement." 64 This higher notion is the ideal commitment of the legal profession to create access to justice, promote fairness, and ensure equity for the poorest members of our society. Clinical professors play an indispensable role in training the next generation of agents of social change and thus should be willing to place a much-needed emphasis on social justice issues in the clinical curriculum.

62 CAP utilizes a leadership model to train students. The student participants are encouraged to be leaders in the community by becoming informed citizens and advocating for justice.

63 Presently, there is a need to increase access to justice. "[...] our justice system is predicated on the assumption that when there is a dispute, all parties will be represented by lawyers who will protect their clients' interests and help their clients navigate the complex legal system. In this sense, lawyers are the gatekeepers to justice. Unfortunately, the most vulnerable members of our society are the least able to afford legal services and are unable to access justice. Law schools have an important role to play in solving the access to justice problem." How to identify the professors and administrators who will support and inspire, Newsweek, http://ejwguide.newsweek.com/chapters/faculty.htm (last visited May 30, 2008).

64 Nelson Mandela Institute, available at http://www.mandelainstitute.org.za/ubuntu.aspx (last visited July 1, 2008). 